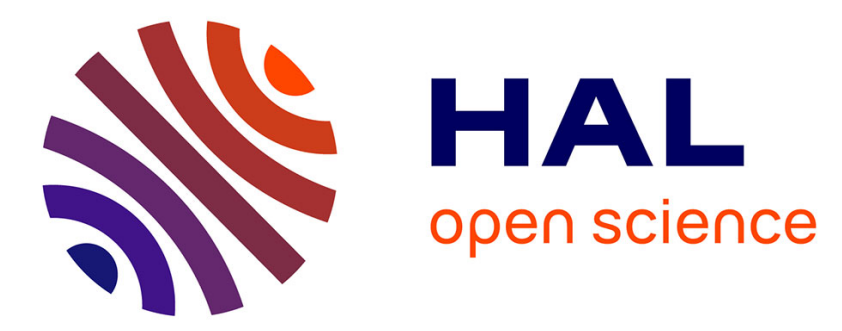

\title{
InSAR analysis of a blind thrust rupture and related active folding: the 1999 Ain Temouchent earthquake ( 5.7, Algeria) case study
}

Samir Belabbès, Mustapha Meghraoui, Ziyadin Çakir, Youcef Bouhadad

\section{- To cite this version:}

Samir Belabbès, Mustapha Meghraoui, Ziyadin Çakir, Youcef Bouhadad. InSAR analysis of a blind thrust rupture and related active folding: the 1999 Ain Temouchent earthquake ( 5.7, Algeria) case study. Journal of Seismology, 2008, 13 (4), pp.421-432. 10.1007/s10950-008-9135-x . hal-00478440

\author{
HAL Id: hal-00478440 \\ https://hal.science/hal-00478440
}

Submitted on 30 Apr 2010

HAL is a multi-disciplinary open access archive for the deposit and dissemination of scientific research documents, whether they are published or not. The documents may come from teaching and research institutions in France or abroad, or from public or private research centers.
L'archive ouverte pluridisciplinaire HAL, est destinée au dépôt et à la diffusion de documents scientifiques de niveau recherche, publiés ou non, émanant des établissements d'enseignement et de recherche français ou étrangers, des laboratoires publics ou privés. 


\title{
InSAR analysis of a blind thrust rupture and related active folding: the 1999 Ain Temouchent earthquake $\left(M_{w}\right.$ 5.7, Algeria) case study
}

\author{
Samir Belabbès • Mustapha Meghraoui • \\ Ziyadin Çakir · Youcef Bouhadad
}

Received: 5 March 2008 / Accepted: 28 August 2008 / Published online: 14 October 2008

(C) Springer Science + Business Media B.V. 2008

\begin{abstract}
We study the surface deformation associated with the 22 December 1999 earthquake, a moderate sized but damaging event at Ain Temouchent (northwestern Algeria) using Interferometric Satellite Aperture Radar images (InSAR). The mainshock focal mechanism solution indicates reverse faulting with a NE-SW trending rupture comparable to other major seismic events of this section of the Africa-Eurasia plate boundary. Previously, the earthquake fault parameters were, however, poorly known because no aftershocks were precisely determined and no coseismic surface ruptures were observed in the field. Using a pair of ERS data with small baseline and short temporal separation in the ascending orbit we obtained an interferogram that shows
\end{abstract}

S. Belabbès · M. Meghraoui

Institut de Physique du Globe de Strasbourg,

UMR 7516, Strasbourg 67084, France

Z. Çakir

Department of Geology, Istanbul Technical

University, Istanbul, Turkey

Y. Bouhadad

Centre du Génie Parasismique (CGS),

Algiers, Algeria

M. Meghraoui $(\varangle)$

EOST-IPG Strasbourg, 5 rue René Descartes 67084,

Strasbourg Cedex, France

e-mail: mustapha@eost.u-strasbg.fr the coseismic surface displacement field despite poor coherence. The interferogram measures four fringes and displays an ellipse-shaped lobe with $\sim 11 \mathrm{~cm}$ peak line-of-sight displacement. The elastic modeling using a boundary element method (Poly3Dinv) indicate coseismic slip reaching up to $1 \mathrm{~m}$ at $5 \mathrm{~km}$ depth on the $\mathrm{N} 57^{\circ} \mathrm{E}$ trending, dipping $32^{\circ} \mathrm{NW}$ Tafna thrust fault. The geodetic estimate of seismic moment is $4.7 \times 10^{17} \mathrm{~N} \mathrm{~m}$. (Mw 5.7) in is good agreement with seismological results. The elliptical shape of the surface displacement field coincides with the NE-SW trending Berdani fault-related fold. The consistency between the geological observations and InSAR solution shed light on the precise earthquake location and related Tafna fault parameters.

Keywords InSAR • Algeria • Earthquake • Thrust fault $\cdot$ Active folding

\section{Introduction}

On 22 December 1999, the city of Ain Temouchent and surrounding area located on the northwestern Tell Atlas mountains were affected by a moderate-sized earthquake (Mw 5.7, EMSC). The mainshock epicenter was located at $1.3^{\circ} \mathrm{W} 35.25^{\circ} \mathrm{N}$ by the Algerian Geophysical Centre (CRAAG) and $1.22^{\circ} \mathrm{W} 35.17^{\circ} \mathrm{N}$ by the 
SED-ETH Zurich (Figs. 1 and 2). Focal mechanism solutions indicate a NE-SW striking reverse fault planes, and the seismic moment reaches $4.37 \times 10^{17} \mathrm{Nm}$ (EMSC, Table 1). Using the waveform modeling, Yelles et al. (2004) obtain Mo $=4.1 \times 10^{17} \mathrm{Nm}$ and estimate a simple rupture process with $5.0 \mathrm{~s}$ source duration. The isoseismal map displays contours elongated in the NE-SW direction and a maximum intensity of VII with a radius of $30 \mathrm{~km}$ within the epicentral area (Yelles et al. 2004). Large historical earthquakes affected this region of the Tell Atlas (e.g., in 1790 with Io X MKS in Oran; in 1819 with Io X MKS in Mascara; (Rothé 1950)) and imply a high seismic potential of this section of the Africa-Eurasia plate boundary (Fig. 1). However, no accurate aftershocks location that could contribute to a clear identification of the seismogenic fault geometry was determined, and no surface ruptures were observed. The precise fault location and related rupture parameters of the 22 December 1999 Ain Temouchent earthquake remained unknown.

The SAR interferometry is able to assess the coseismic surface deformation which provides access to the rupture parameters (Burgmann et al. 2000; Wright et al. 2004; Fielding et al. 2004; Cakir et al. 2006; Motagh et al. 2006; Belabbes 2008). Although it is relatively easy to determine the surface deformation of large earthquakes $(\mathrm{Mw} \geq 6)$ with InSAR, even with long temporal separation between SAR images, it is often difficult to reveal the surface deformation of small- and moderate-sized earthquakes $(\mathrm{Mw}<6$; Lohman and Simons 2005). However, under favorable conditions (e.g., short temporal and spatial baselines), InSAR may provide significant results for small- and moderate-sized shallow

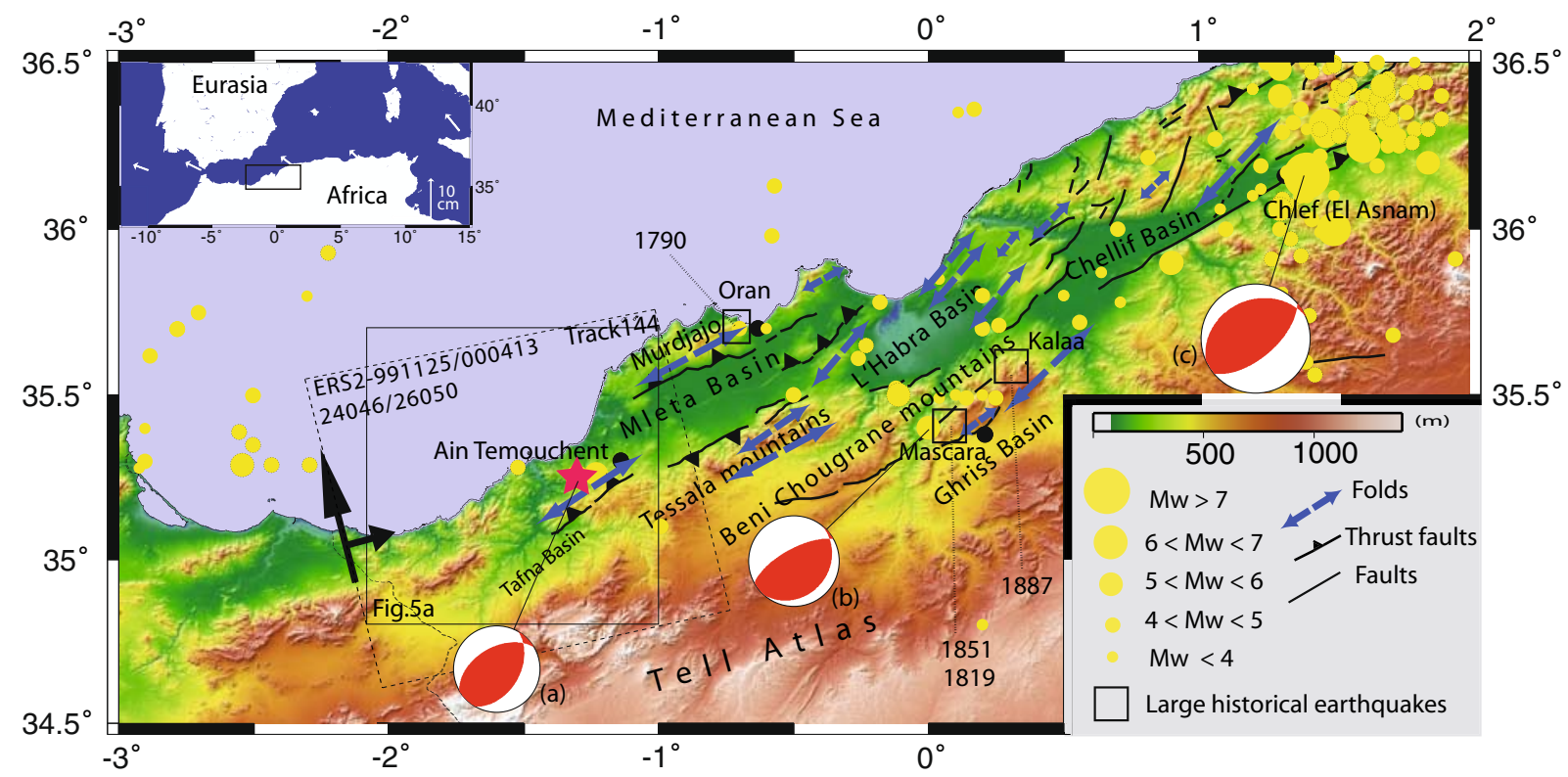

Fig. 1 Seismotectonics of the Ain Temouchent earthquake area with shaded relief image from SRTM data. The 1999 Ain Temouchent mainshock location (red star) is from CRAAG and the seismicity from Benouar (1994) 19001993 catalogue and ISC 1993-2006 catalogue. Circles are for instrumental events and squares for main historical events. Beach balls $\mathbf{a}, \mathbf{b}$, and $\mathbf{c}$ are the focal mechanism solutions of the 1999 Ain Temouchent (Mw 5.7), 1994 Mascara, (Mw 5.7) and the $1980 \mathrm{El}$ Asnam (Mw 7.3) earthquakes, respectively (from Global CMT). Active folds and faults are from Meghraoui (1988). Dashed box shows the ERS SAR data frame (track 144) and black arrows indicate the satellite flight direction (ascending) and the line of sight direction (towards east). Inset box shows the convergence between African and Eurasian plates in western Mediterranean with white arrows indicating the motion of Africa relative to Eurasia (Serpelloni et al. 2007) 
Fig. 2 Morphotectonic map of the earthquake area. Stars show the earthquake epicenter given by different seismological centers. The arrowed line shows the fold orientation. Black line with thrust symbols shows the modeled fault (see also Figs. 8 and 9). Dashed line indicates the active fault extension. $T$ is the cross-section of Fig. $9 \mathrm{~b}$

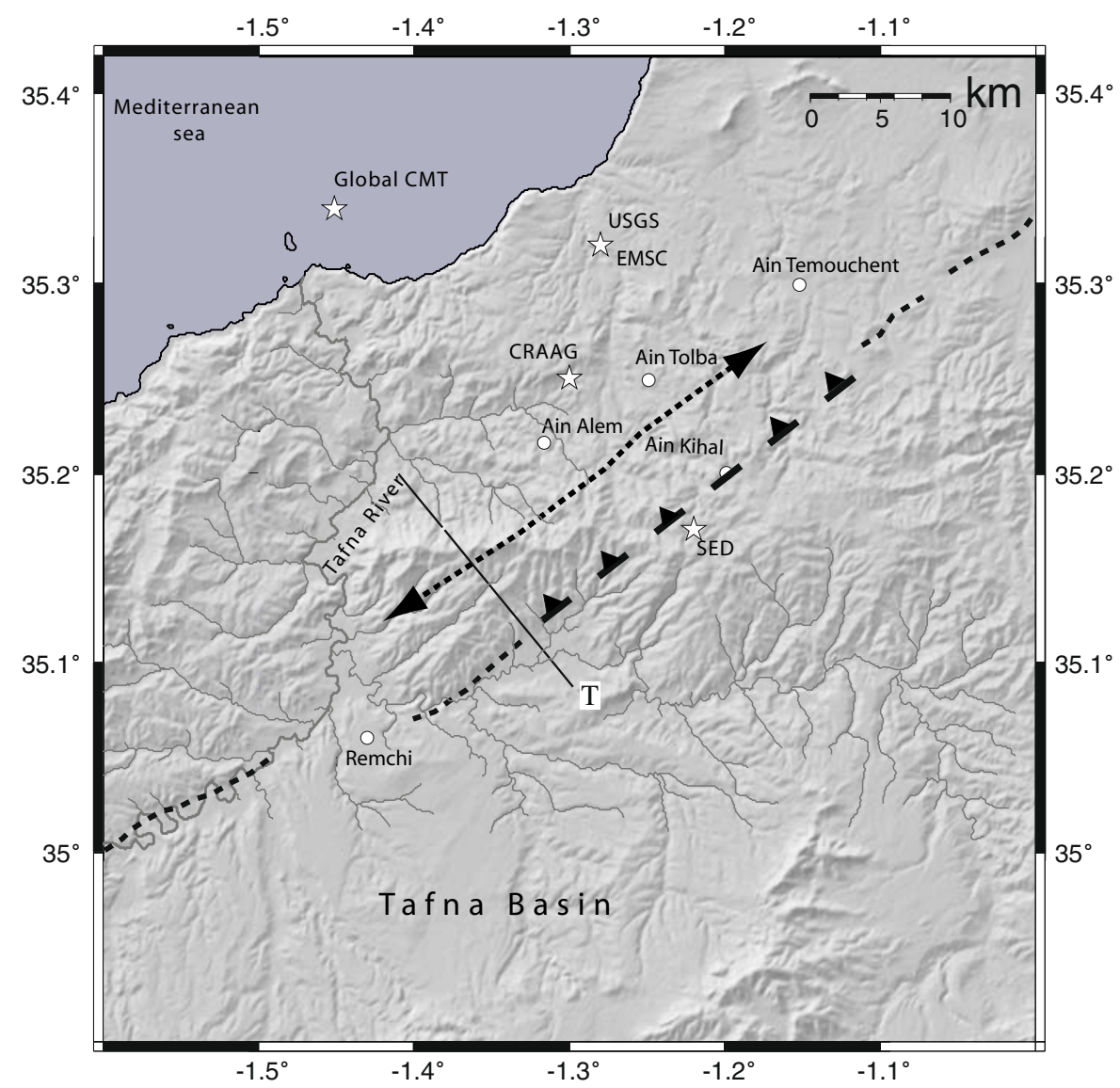

earthquakes even in regions with variable topography and dense vegetation (Salvi et al. 2000; Mellors et al. 2004; Akoglu et al. 2006).

SAR interferometry applied to the 1994-2004 (Mw 6.0; 6.4) Al Hoceima earthquake sequence in North Africa (Cakir et al. 2006; Akoglu et al. 2006) revealed blind NE-SW and NW-SE conjugate strike-slip faults affecting the Rif Mountains.
For the Mw 6.8, 2003 Zemmouri (Northern Algeria) earthquake, the InSAR results suggest a NE-SW trending and 50-km-long thrust rupture with two offshore fault segments and $\sim 0.15 \mathrm{~m}$ induced right-lateral slip on an E-W fault (Belabbes 2008).

In this paper, we use ERS Synthetic Aperature Radar (SAR) data to compute coseismic inter-

Table 1 Rupture parameters of the 22/12/1999 Ain Temouchent earthquake

\begin{tabular}{|c|c|c|c|c|c|c|c|c|c|c|}
\hline \multirow[t]{2}{*}{ Source } & \multirow[t]{2}{*}{ Long $\left(^{\circ}\right)$} & \multirow[t]{2}{*}{ Lat $\left(^{\circ}\right)$} & \multirow[t]{2}{*}{ Depth (km) } & \multicolumn{3}{|l|}{ Plane1 } & \multicolumn{3}{|l|}{ Plane2 } & \multirow[t]{2}{*}{$\mathrm{Mo}(\mathrm{Nm})$} \\
\hline & & & & Strike & Dip & Rake & Strike & Dip & $\overline{\text { Rake }}$ & \\
\hline$\overline{\mathrm{HRV}}$ & -1.45 & 35.34 & 15 & $29^{\circ}$ & $45^{\circ}$ & $67^{\circ}$ & $240^{\circ}$ & $49^{\circ}$ & $111^{\circ}$ & $2.95 \times 10^{17}$ \\
\hline SED & -1.22 & 35.17 & 12 & $221^{\circ}$ & $57^{\circ}$ & $80^{\circ}$ & $59^{\circ}$ & $34^{\circ}$ & $106^{\circ}$ & $4.26 \times 10^{17}$ \\
\hline USGS & -1.28 & 35.32 & - & - & & - & - & - & - & - \\
\hline EMSC & -1.28 & 35.32 & 8 & $59^{\circ}$ & $21^{\circ}$ & $118^{\circ}$ & $209^{\circ}$ & $71^{\circ}$ & $80^{\circ}$ & $4.7 \times 10^{17}$ \\
\hline Yelles et al. & $-1.3^{\mathrm{a}}$ & $35.25^{\mathrm{a}}$ & 4 & $60^{\circ}$ & $36^{\circ}$ & $63^{\circ}$ & $272^{\circ}$ & $54^{\circ}$ & $108^{\circ}$ & $4.1 \times 10^{17}$ \\
\hline This study & $-1.3^{\mathrm{a}}$ & $35.25^{\mathrm{a}}$ & 5 & $57^{\circ}$ & $32^{\circ}$ & $90^{\circ}$ & $237^{\circ}$ & $58^{\circ}$ & $90^{\circ}$ & $4.7 \times 10^{17}$ \\
\hline
\end{tabular}

$H R V$ Harvard, SED Swiss Seismological Network, USGS US Geological Survey, EMSC Euro-Mediterranean Seismological Center

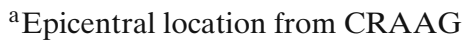


ferograms of the Ain Temouchent earthquake, locate the area of surface deformation and infer the fault rupture characteristics. In parallel, InSAR results and field observations, which show evidence of Quaternary deformation and active folding in the epicentral area, are combined to obtain fault parameters. Using Poly3Dinv inversion software, we obtain a dislocation model with slip distribution at depth that constrains the seismic rupture parameters. Finally, we discuss the application of InSAR to the identification of blind thrust fault rupture and its implication for the seismic hazard evaluation in northern Algeria.

\section{Tectonic setting}

The Ain Temouchent earthquake area is located in the Tell Atlas, immediately NE of the Tafna Quaternary basin and SE of the Mleta Quaternary basin (Figs. 1 and 2). The intensity map related to damage delimits a zone around Ain Temouchent city including Ain Allem, Ain Tolba, and Ain Kihal villages (Fig. 2; Yelles et al. 2004), but no surface faulting were visible (Bouhadad 2007). The Mleta basin is limited to the north by the $\mathrm{N} \mathrm{50} 0^{\circ}$ trending and 32-km-long Murdjadjo active fold-related fault that may be responsible for the 1790 Oran earthquake $\left(I_{0}=X-\right.$ XI MKS, Rothé 1950; Bouhadad 2001). East of the epicentral area, the Tessala and Beni Choughrane mountains and NE-SW fold-related faults experienced the 1994 Mascara thrust earthquake (Benouar et al. 1994; Mw 5.7, Fig. 1) which is comparable to the Ain Temouchent 1999 event, since it did not produce surface faulting. The recent major earthquakes of El Asnam (1980, Mw 7.3), Tipaza (1989, Mw 5.9), Mascara (1994, Mw 5.7), and Zemmouri (2003, Mw 6.8) in northwest Algeria illustrate the pattern of active deformation in the Tell Atlas. The tectonic characteristics correspond to thrust ruptures associated with NE-SW trending foldrelated faults showing en-echelon right-stepping distribution (Meghraoui 1988, 1991; Benouar et al. 1994; Meghraoui and Doumaz 1996). The late Quaternary active deformation of the Tell Atlas mountain ranges of northwest Algeria consists of NE-SW trending thrust and fold system that result from 3 to $6 \mathrm{~mm} /$ year convergent movements between Africa and Eurasia (Nocquet and Calais 2004; Serpelloni et al. 2007). The transpressive active deformation is essentially due to the NNWSSE to NW-SE shortening as inferred from $P$ axes of thrust focal mechanisms (Meghraoui et al. 1996; Stich et al. 2003).

Field investigations in the earthquake area indicate the existence of NE-SW trending folded Neogene and Quaternary units with steep southeastern flank and thrust fault that controls the Tafna Basin (Fig. 2). In particular, the Berdani fold structure runs for more than $\sim 20 \mathrm{~km}$ in the epicentral zone, from the Tafna River in the southwest to the Ain Kihal village in the northeast. The fold structure is bounded to the southeast by a single linear fault scarp morphology and presents $\sim 300 \mathrm{~m}$ topographic offset near the Tafna Basin (Fig. 2). Furthermore, minor reverse faults and liquefaction features that affect Quaternary units are visible along scarp morphology (Bouhadad 2007). Other evidence of recent tectonic activity is attested by (1) strongly folded late Quaternary units and alluvial terraces visible in the southeastern flank of the anticline (Figs. 2 and 3, ref: Geological map of Bensekrane 1990) and (2) the relationships between the morphology and the drainage network. The analysis of topography suggests that the 40-km-long Tafna fault crosses the Tafna River and extends towards the SW. The Tafna fault is associated with cumulative uplift of alluvial units and triangular facets with progressive angular inconformity of late Quaternary units. Active tectonics of the Ain Temouchent region indicate the existence of a previously unknown Tafna fault and related Berdani fold with seismic characteristics comparable to other active zones in the Tell Atlas (Table 2).

\section{InSAR data analysis}

In order to map the surface displacement field, we calculated four coseismic interferograms using the European Space Agency (ESA) ERS-2 SAR data from the ascending orbits (Fig. 4; Table 3). With multi-looking of 5 in azimuth and 1 in range (i.e., averaged to $20 \times 20 \mathrm{~m}$ of ground pixel size), 
Fig. 3 Satellite image of the epicentral area showing the Berdani fold structure (from Google Earth). White star is the epicenter of the 1999 earthquake determined by CRAAG with focal mechanism from Global CMT. The fault scarp location (black line) is delineated by the triangular facets, progressive unconformity of Quaternary units and uplifted alluvial deposits (see also the cross-section in Fig. 9a)

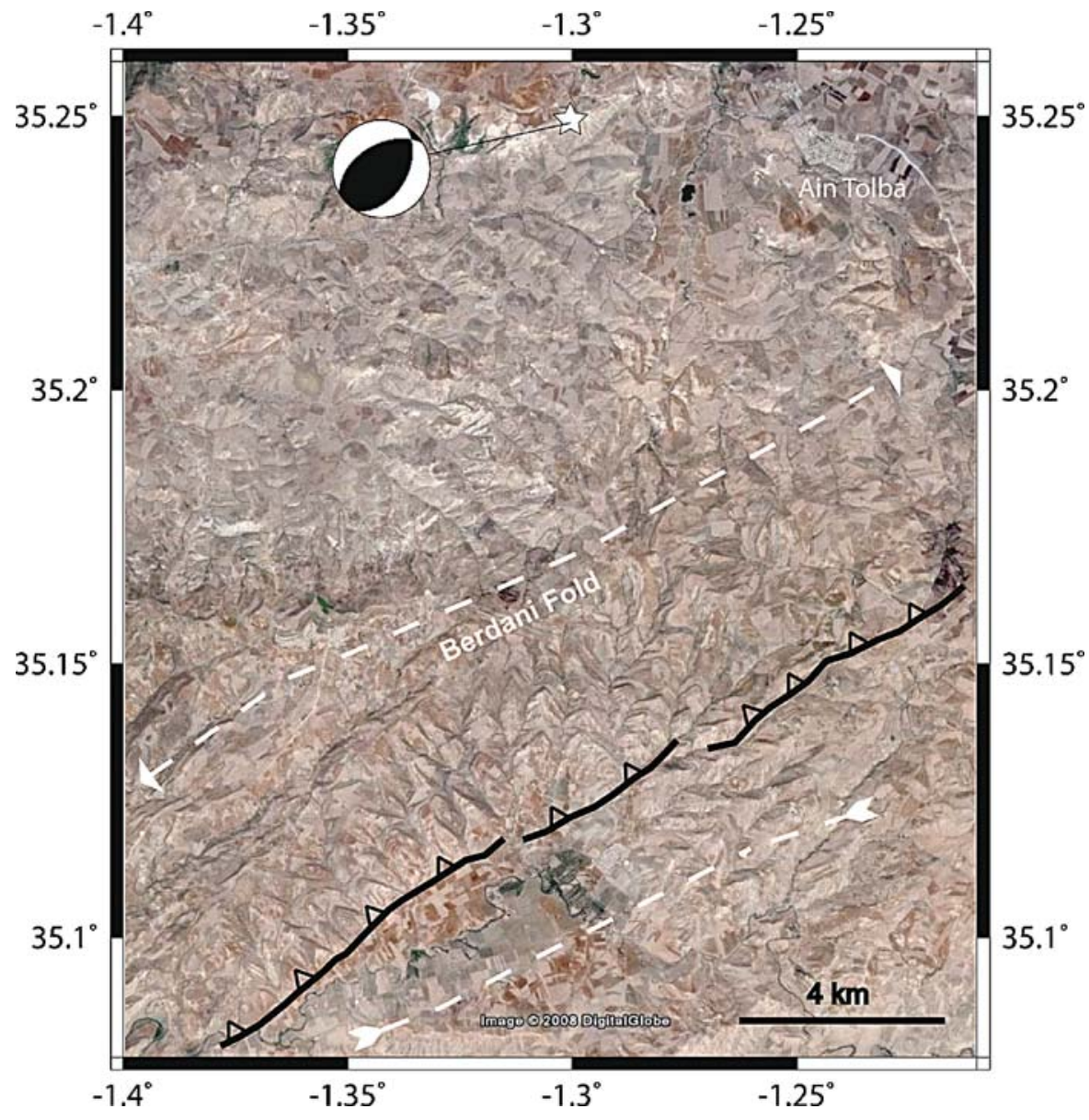

the raw data were processed with SARscape ${ }^{\circledR}$ software and satellite precise orbits (from Delft University; Scharoo and Visser 1998). The processing takes into account a spatial baseline variation of satellite orbits from 0 to $\sim 1,000 \mathrm{~m}$ and the phase difference of interferograms that may include surface displacement (tectonic), topographic effects, noise from the atmospheric effects, and orbit errors (Massonnet and Feigl 1998;
Burgmann et al. 2000). We used the SRTM $3^{\prime \prime}(\sim 90 \mathrm{~m})$ posting digital elevation model to remove the effect of topography from the interferograms (Farr and Kobrick 2000). Interferograms with large temporal and/or spatial baselines do not provide deformation fringes due to signal decorrelation resulting mainly from surface changes (not tectonic, e.g., the seasonal vegetation change from spring to fall); in this case, the decorrelation
Table 2 Major large to moderate thrust faulting earthquakes of the Tell Atlas of Algeria

\begin{tabular}{llcll}
\hline Location & Date & Long $\left(^{\circ}\right)$ & Lat $\left(^{\circ}\right)$ & $\mathrm{Mw}$ \\
\hline Orleanville & $09 / 09 / 1954$ & 1.47 & 36.28 & 6.7 \\
El Asnam & $10 / 10 / 1980$ & 1.36 & 36.18 & 7.3 \\
Constantine & $27 / 10 / 1985$ & 6.65 & 36.4 & 6 \\
Tipaza & $29 / 10 / 1989$ & 2.92 & 36.84 & 5.9 \\
Mascara & $18 / 08 / 1994$ & -0.03 & 35.40 & 5.7 \\
Ain Temouchent & $22 / 12 / 1999$ & -1.45 & 35.34 & 5.7 \\
Beni Ourtilane & $10 / 11 / 2000$ & 4.69 & 36.71 & 5.7 \\
Zemmouri & $21 / 05 / 2003$ & 3.65 & 36.83 & 6.8 \\
\hline
\end{tabular}


Fig. 4 Baseline plot of the SAR data used in this study ( $x$-axis is in year/month/day). The pair with a bold line is the interferogram shown in Fig. 5

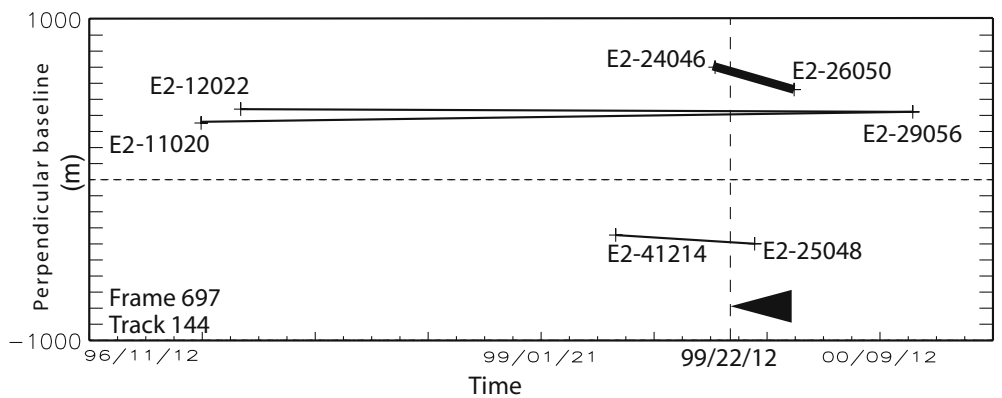

increases with time and may cancel the fringe of interferograms (Massonnet and Feigl 1998; Lohman and Simons 2005). Therefore, for shallow, small- to moderate-sized earthquakes, we select SAR pairs with short temporal and spatial baselines.

Among the four interferograms, the best is the one with the shortest time interval (i.e., 5 months) and $130 \mathrm{~m}$ perpendicular baseline (Fig. 4; Table 3). The interferogram shows $\sim 11 \mathrm{~cm}$ slip in the line of sight that corresponds to four fringes in an elliptical lobe (Fig. 5). Orbital residuals parallel to the range direction were removed from the interferogram with a first-order polynomial function. Centered in the epicentral area determined by CRAAG, the elliptical lobe is $\sim 20 \mathrm{~km}$ long, $\sim 10 \mathrm{~km}$ wide, and trends NE-SW (Fig. 5), consistent with the focal mechanism solution and late Quaternary folding described above (see previous paragraph and Figs. 2, 3, and 5). The fault location is indicated by the steep fringe gradient to the south side of the lobe. Comparable fringes with elliptical lobe associated with folding can be also seen in other cases like the 1994 Sefidabeh earthquake $\left(M_{w} 6\right.$ in eastern Iran; Parsons et al. 2006). The coseismic interferogram allows us to resolve the ambiguity of the fault rupture location, dip direction, and displacement field of the Ain Temouchent earthquake.

\section{Modeling of a blind thrust rupture}

In order to model the SAR data, we use the Poly3Dinv inversion method based on the analytical solution for an angular dislocation (triangulated surfaces as discontinuities) in a linear, elastic, homogeneous, and isotropic half space (Maerten et al. 2005; Okada 1985). The fringes shape and the Berdani fold geomorphology indicate that the 1999 fault rupture is most likely dipping NW and located SE of the deformation lobe. We meshed our surfaces with 70 triangles (i.e., $7 \times 5$ quadrangles) using MATLAB ${ }^{\circledR}$. Because of the low coherence and difficulties in unwrapping phases, we use digitized fringes that are also visible in the wrapped interferogram. The slip distribution in each triangular element is inverted with a negativity constraint on the dip slip component (i.e., thrusting only), and a minimum RMS is calculated for the best fit of fault geometry (Fig. 6a). In addition, to avoid unphysical oscillatory slip, the scale-dependent umbrella smoothing operator in Poly3Dinv is applied using
Table 3 References of SAR images

\begin{tabular}{lllll}
\hline Satellite & Orbit number & Date & Track & Frame \\
\hline ERS-1 & 41214 & $02 / 06 / 1999$ & 144 & 697 \\
ERS-2 & 29056 & $09 / 11 / 2000$ & 144 & 697 \\
ERS-2 & 24046 & $25 / 11 / 1999$ & 144 & 697 \\
ERS-2 & 12022 & $07 / 08 / 1997$ & 144 & 697 \\
ERS-2 & 25048 & $03 / 02 / 2000$ & 144 & 697 \\
ERS-2 & 26050 & $13 / 04 / 2000$ & 144 & 697 \\
\hline
\end{tabular}




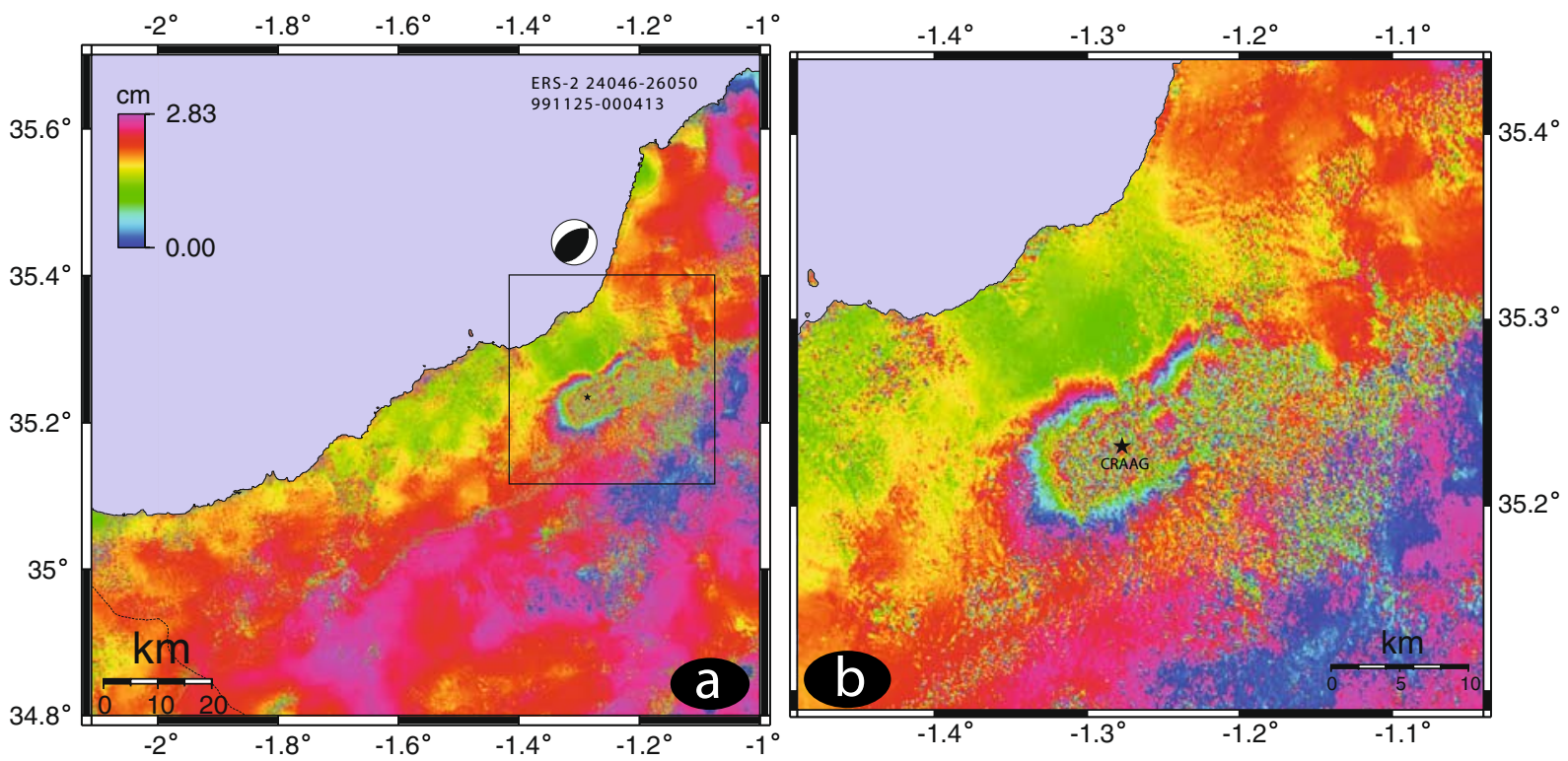

Fig. 5 a ERS2 coseismic interferogram of the 1999 Ain Temouchent earthquake. b Enlarged area of (a). showing an elliptical lobe with up to $11 \mathrm{~cm}$ (four fringes) slip along the radar line of sight

Fig. 6 a Plot of rms misfit versus fault dip. The best result is obtained with a fault dip of $32^{\circ}$ to the northwest. b Plot of rms misfit versus smoothing factor and model roughness. A smoothing factor of 0.3 represents the best compromise between the smoothness of solution and fit
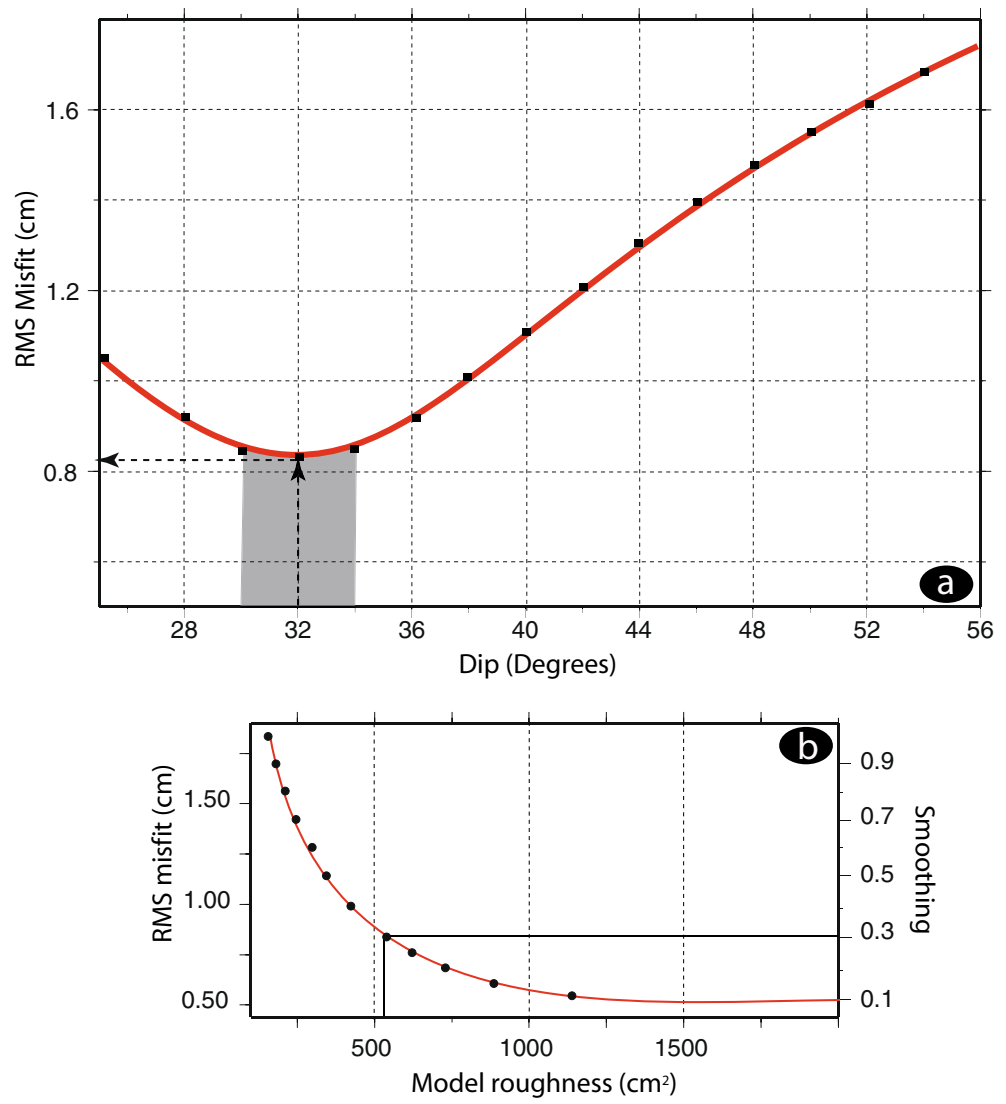


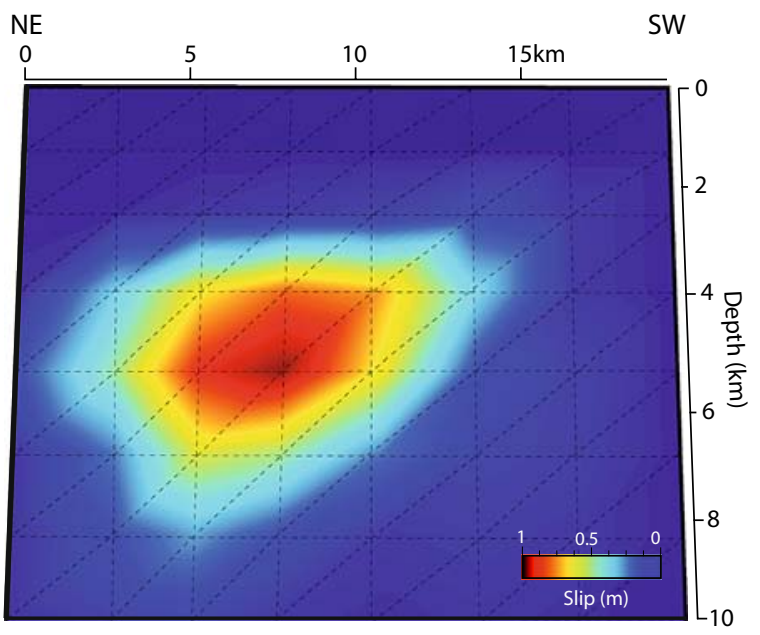

Fig. 7 Slip distribution of the best fit model for the Ain Temouchent earthquake. The maximum slip reaches $1 \mathrm{~m}$ at about $5 \mathrm{~km}$ depth

a 0.3 factor to invert slip distribution. This value is the best compromise between the roughness of the model and the fit with the data (Fig. 6b). Since the coseismic fault rupture was not observed at the surface, we consider the fault as blind with no slip on the upper quadrangles and run series of inversions in order to constrain the fault geometry at depth. The coseismic slip is inverted on $20^{\circ}$ to $60^{\circ} \mathrm{NW}$ dipping faults that coincide at surface with the trace of the Tafna fault.

As shown in Figs. 6a and 7, the best fit is obtained with a $20-\mathrm{km}$-long thrust fault striking $\mathrm{N}$ $57^{\circ} \mathrm{E}$ and dipping $32^{\circ} \mathrm{NW}$. The inferred fault trace located at about $5 \mathrm{~km}$ south of the deformation fringes coincides with the southeastern flank of the Berdani fold (Fig. 8a). Our best slip model also indicates one single patch with a maximum slip of $1 \mathrm{~m}$ at $5 \mathrm{~km}$ depth (Fig. 7) and a geodetic moment of $4.7 \times 10^{17} \mathrm{~N} \mathrm{~m}(\mathrm{Mw} 5.7)$ in good agreement with seismological estimates of Table 1. Main features of the observed interferograms are successfully reproduced by the best fit model (Fig. 8a). This is also supported by the $\sim 0.8 \mathrm{~cm}$ RMS values (Fig. 6a) and low residual fringes (Fig. 8b).

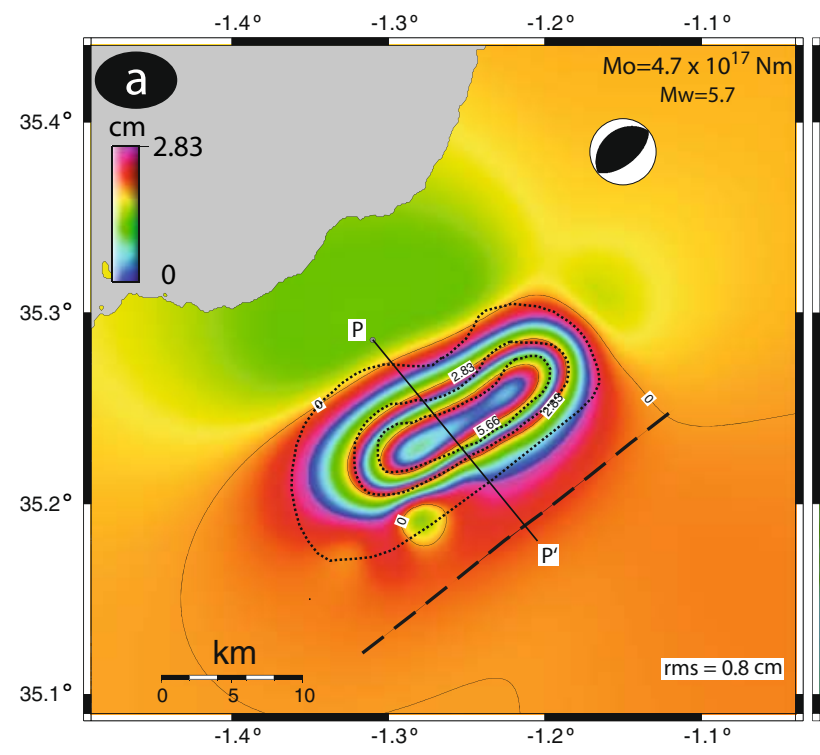

Fig. 8 a Synthetic interferogram obtained from the inversion. Geodetic moment (Mo) and the corresponding moment magnitude $(\mathrm{Mw})$ of the earthquake are consistent with those determined from seismology (Table 1). Thick dashed line represents the surface trace of the modeled fault. b Residual interferogram

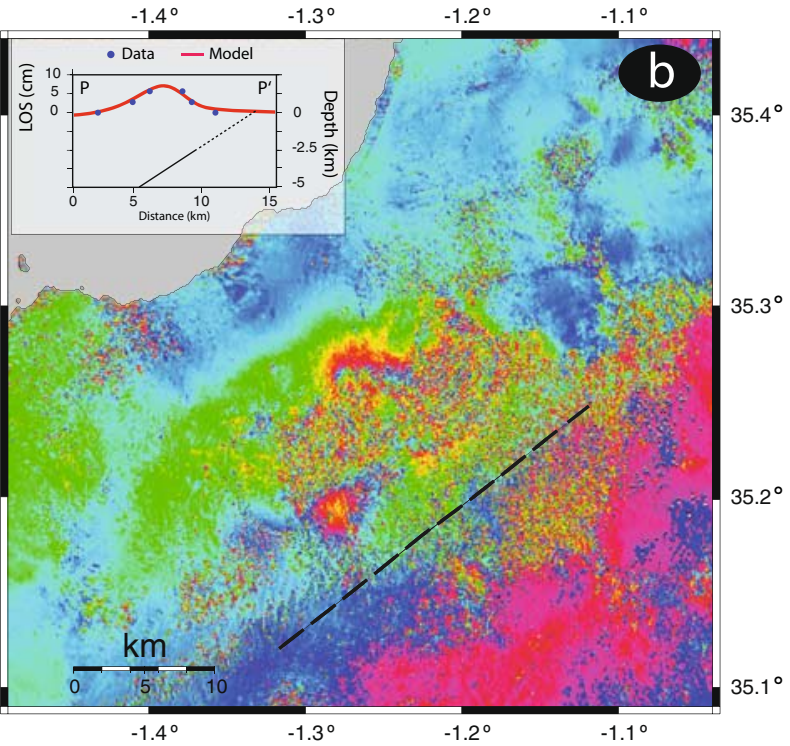

obtained after subtracting the synthetic interferograms from the observed interferogram (Fig. 5). Inset profile illustrates the fit between the model and data. The small feature visible SW of the modeled fringes and in the residuals can be considered as an artefact because it does not appear in the interferogram of Fig. 5 
Fig. 9 Cross-sections (location in Fig. 2) of the earthquake area with a Geology (Ref:

Geological map of Bensekrane 1990). b Topographic profile (vertical exaggeration: 5) and c Dislocation model. The southeast verging Berdani fold and related active fault are responsible of the topographic offset, surface deformation. The cumulative slip which reflects several earthquake cycles on the fault is attested by the unconformity of the Quaternary deposits and the bending normal faults on the anticline
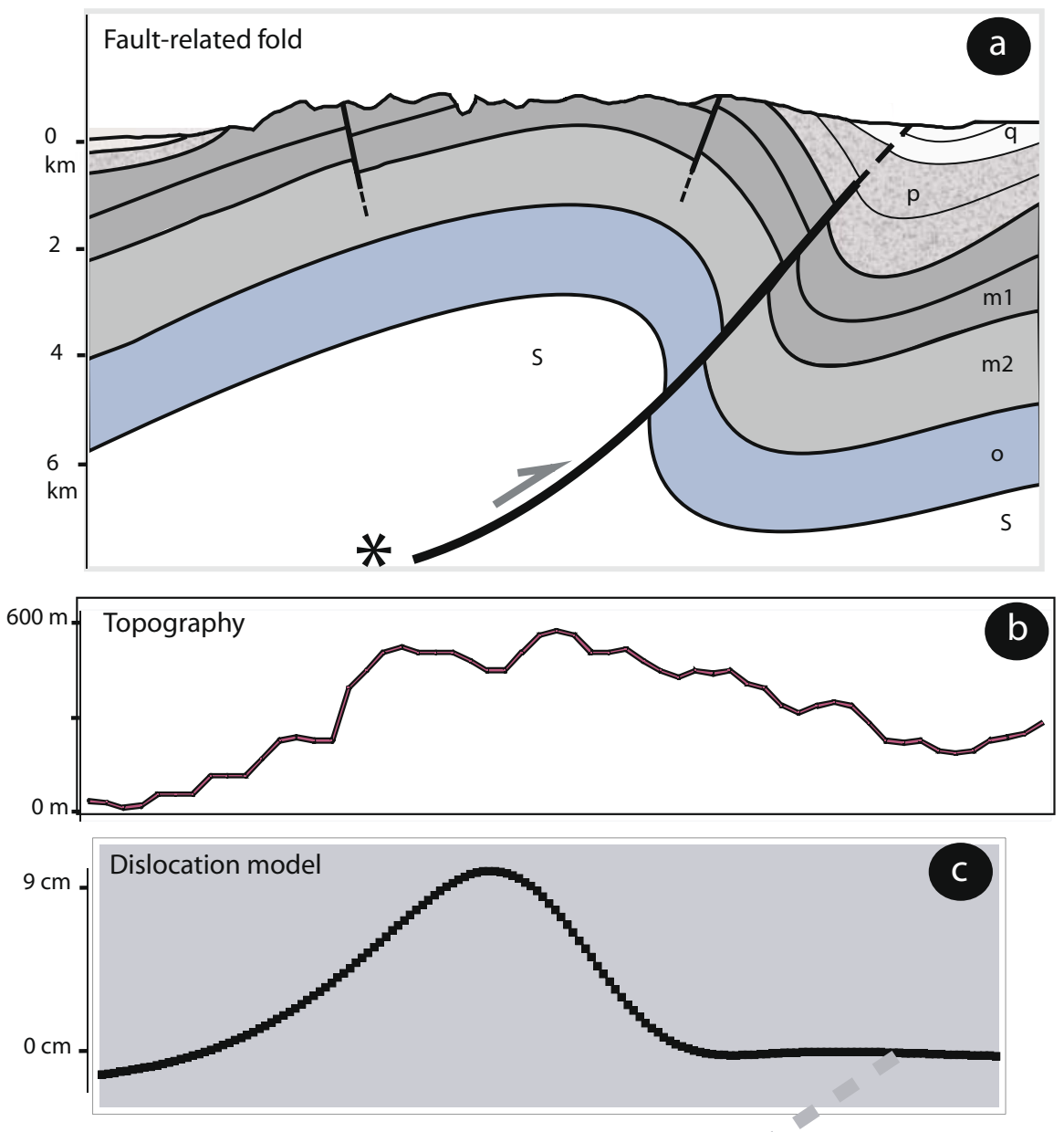

\begin{tabular}{l}
\hline Legend: \\
s: pre-oligocene substratum \\
o: Oligocene \\
m1: Lower Miocene \\
m2: Upper Miocene \\
p: Pliocene \\
q: Quaternary \\
* Hypocenter \\
\hline
\end{tabular}

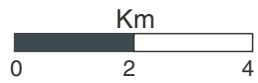

\section{Discussion and conclusion}

The surface deformation of the 22 December, 1999 (Mw 5.7) Ain Temouchent earthquake is documented using InSAR analysis and related modeling supported by field observations. In the absence of surface faulting and accurate aftershocks location, the high-resolution of InSAR results (four fringes in an elliptical lobe) complemented by field investigations help in constraining the area of surface deformation associated with a moderate-sized earthquake. Deformation fringes corroborated by the thrust focal mechanism solution (Harvard) show a NE-SW trending and NW dipping rupture related to an active folding deformation in the 1999 epicentral zone. The 
modeling of InSAR data allowed us to constrain the geodetic moment of $4.7 \times 10^{17} \mathrm{~N} \mathrm{~m}(\mathrm{Mw} 5.7)$ with a maximum slip of $1 \mathrm{~m}$ at $5 \mathrm{~km}$ depth. The Ain Temouchent earthquake took place on a $\sim 20$ km-long thrust fault, striking $\mathrm{N} 57^{\circ} \mathrm{E}$ and dipping $32^{\circ} \mathrm{NW}$.

The NW dipping fold-related fault is comparable to those previously described in the Cheliff and Habra Basins (Fig. 1; Meghraoui 1988; Bouhadad 2001). The Berdani anticline structure also exhibits normal faults comparable to the bending moment fault associated with the Oued Fodda fold of the El Asnam fault (Meghraoui and Doumaz 1996). The structural framework of the 1999 Ain Temouchent earthquake is characterized by fold-related thrust tectonics where deformed late Quaternary deposits illustrate the cumulative deformation of numerous earthquake cycles (Fig. 9). The fold growth is here also controlled by the incremental coseismic fault movements as shown by the existence of the bending moment normal faults, the progressive unconformity of Quaternary deposits, and uplifted alluvial terraces southeast of the Berdani anticline (Fig. 3). The comparison between the south verging broken anticline, the offset topographic profile across the Tafna Basin and Berdani fold, and the zone of maximum deformation as predicted by dislocation model (Fig. 9c) indicates clear relationships between the blind thrust rupture geometry, the coseismic surface deformation and local geology. The fact that the zone of maximum surface deformation is located at about $5 \mathrm{~km} \mathrm{NW}$ of the fault scarp (Figs. 3 and 5b) reflects the blind character of the coseismic rupture. However, the complex geomorphology likely related to the inherited Cenozoïc tectonic structures (Geological map of Bensekrane 1990) tends to hide the late Quaternary deformation (see also the structural cross section of Fig. 9a and topographic profile of Fig. 9b).

The 1999 rupture occurred on one segment of the fault which extends further SW and dams the Tafna River (Fig. 2) in a situation similar to the damming of the Cheliff River by the El Asnam fault (Meghraoui and Doumaz 1996). An earthquake rupture along the entire Tafna fault length ( $\sim 40 \mathrm{~km}$, Fig. 2) would generate an $\mathrm{Mw}>7$ earthquake according to the Wells and Coppersmith empirical relations (1994). The fault parameters obtained by Yelles et al. (2004) are slightly different from our results (Table 1). Indeed, the InSAR analysis is based on near-field observations, and it has, therefore, a better constraint on the rupture location, strike, and size. In contrast, the seismic source modeling (Yelles et al. 2004) has more control on the faulting mechanism and associated rake angle (Table 1). The tectonic pattern of blind or hidden thrust rupture is also a characteristic of the Tell Atlas of Algeria that experienced several moderate-sized earthquakes in the last two decades (Meghraoui 1991; Bounif et al. 1987; Benouar et al. 1994, Table 2). More recently, field observations and InSAR analysis of the 2003 Zemmouri earthquake (Mw 6.8) revealed an average $0.60 \mathrm{~m}$ uplift along a $55-\mathrm{km}$ coastline associated with a NE-SW trending offshore thrust fault (Meghraoui et al. 2004; Belabbes 2008). The largest instrumentally recorded seismic event of the Tell Atlas reached Mw 7.3 in 1980 at El Asnam and reactivated 36-km-long thrust fault and related folding with a $2.5 \mathrm{~m}$ average vertical offset (Philip and Meghraoui 1983). This earthquake made possible the identification of the main seismogenic characteristics of the Tell Atlas active folding and established the relationships between active folding and fault ruptures in many worldwide seismogenic zones (Stein and Yeats 1989). However, shallow and moderate-sized earthquakes associated with folding are frequent in northern Algeria, and the surface deformation induced by these earthquakes is somehow difficult to characterize. In regions with hidden or blind earthquakes and poor seismic array coverage, InSAR is an extremely useful tool that determines the coseismic surface deformation and help in constraining the rupture characteristics.

Acknowledgements This work was funded by the INSU research project ACI Cat-Nat "Risque sismique de la région d'Alger". SAR images were obtained through the Category 1 project 2532 and 2891 of the European Space Agency. Samir Belabbes is supported by the Algerian Ministry of Higher Education through a research studentship. We benefited from numerous discussions with Abdelhakim Ayadi (CRAAG) on the 1999 earthquake sequence. We thank Mahdi Motagh (GFZ Potsdam) and two anonymous reviewers for the comments on an earlier version of the manuscript. Some of the figures were prepared using the public domain GMT software (Wessel and Smith 1998). 


\section{References}

Akoglu AM, Cakir Z, Meghraoui M, Belabbes SOEAS, Ergintav S, Serdar A (2006) The 1994-2004 Al Hoceima (Morocco) earthquake sequence: conjugate fault ruptures deduced from InSAR. Earth Planet Sci Lett 252:467-480. doi:10.1016/j.epsl.2006.10.010

Belabbes S (2008) Caractérisation de la déformation active par l'Interférométrie Radar (InSAR): Failles sismiques aveugles et cachées de l'Atlas Tellien (Algérie) et du Rif (Maroc) le long de la limite des plaques Afrique-Eurasie. PhD thesis, EOSTUniversity Louis Pasteur, Strasbourg, France, 226 pp

Benouar D (1994) Materials for the investigation of the seismicity of Algeria and adjacent regions during the twentieth century. Ann Geophys 37(4):459-860

Benouar D, Aoudia A, Maouche S, Meghraoui M (1994) The 18 August 1994 Mascara (Algeria) earthquake; a quick-look report. Terra Nova 6:634-638. doi:10.1111/j.1365-3121.1994.tb00529.x

Bouhadad Y (2001) The Murdjajo, Western Algeria, faultrelated fold: implications for seismic hazard. J Seismol 5:541-558. doi:10.1023/A:1012039900248

Bouhadad Y (2007) Dynamique récente et actuelle de quelques tronçons de la chaine tellienne: geologie des failles actives et aléa sismique. Doctorat en Sciences Thesis, Université des Sciences et de la Technologie Houari Boumediene, $242 \mathrm{pp}$

Bounif A, Haessler H, Meghraoui M (1987) The Constantine (Northeast Algeria) earthquake of October 27, 1985; surface ruptures and aftershock study. Earth Planet Sci Lett 85:451-460. doi:10.1016/ 0012-821X(87)90140-3

Burgmann R, Ayhan E, Barka A, Durand P, Ergintav S, Feigl K et al (2000) Geodetic studies of the 1999 IzmitDuzce earthquake sequence, $A G U$-EOS Transactions, 2000 Fall Meeting, December 15-19, San Francisco, p. F836

Cakir Z, Meghraoui M, Akoglu AM, Jabour N, Belabbes S, Ait BL (2006) Surface deformation associated with the M (sub w) 6.4, 24 February 2004 Al Hoceima, Morocco, earthquake deduced from InSAR; implications for the active tectonics along North Africa. Bull Seismol Soc Am 96:59-68. doi:10.1785/0120050108

Farr TG, Kobrick M (2000) Shuttle radar topography mission produces a wealth of data. Eos Trans AGU 81:583-585

Fielding EJ, Wright TJ, Muller J, Parsons BE, Walker R (2004) Aseismic deformation of a fold-and-thrust belt imaged by synthetic aperture radar interferometry near Shahdad, southeast Iran. Geology 32:577-580. doi:10.1130/G20452.1

Geological map of Bensekrane (1990) Sheet 1/50000, Published by the Office National de Géologie, Ministry of Mines (Algeria)

Lohman RB, Simons M (2005) Locations of selected small earthquakes in the Zagros Mountains. Geochem Geophys Geosyst 6:Q03001. doi:10.1029/2004GC000849

Maerten F, Resor P, Pollard D, Maerten L (2005) Inverting for slip on three-dimensional fault surfaces using an- gular dislocations. Bull Seismol Soc Am 95:1654-1665. doi:10.1785/0120030181

Massonnet D, Feigl KL (1998) Radar interferometry and its application to changes in the Earth's surface. Rev Geophys 36:441-500. doi:10.1029/97RG03139

Meghraoui M (1988) Geologie des zones sismiques du Nord de l'Algérie. Paléosismologie, Tectonique Active et Synthèse Sismotectonique. PhD Thesis, Université de Paris-Sud Centre d'Orsay, pp 355

Meghraoui M (1991) Blind reverse faulting system associated with the Mont Chenoua-Tipaza earthquake of 29 October 1989 (north-central Algeria). Terra Nova 3:84-92. doi:10.1111/j.1365-3121.1991.tb00847.x

Meghraoui M, Doumaz F (1996) Earthquake-induced flooding and paleoseismicity of the El Asnam, Algeria, fault-related fold. J Geophys Res 101:17, 617-17, 644. doi:10.1029/96JB00650

Meghraoui M, Morel JL, Andrieux J, Dahmani M (1996) Tectonique Plio-Quaternaire de la chaine tello-rifaine et de la mer d'Alboran; une zone complexe de convergence continent-continent. Bull Soc Geol Fr 167: 141-157

Meghraoui M, Maouche S, Chemaa B, Cakir Z, Aoudia A, Harbi A et al (2004) Coastal uplift and thrust faulting associated with the $\mathrm{M}(\mathrm{sub} \mathrm{w})=6.8$ Zemmouri (Algeria) earthquake of 21 May 2003. Geophys Res Lett 31:L19605. doi:10.1029/2004GL020466

Mellors RJ, Magistrale H, Earle P, Cogbill A (2004) Comparison of four moderate-size earthquakes in Southern California. Bull Seismol Soc Am 94:20042014. doi:10.1785/0120020219

Motagh M, Klotz J, Tavakoli F, Djamour Y, Arabi S, Wetzel H, Zschau J (2006) Combination of precise leveling and InSAR data to constrain source parameters of the $\mathrm{Mw}=6.5,26$ December 2003 Bam earthquake. Pure Appl Geophys 163 (2006) 1-18 0033-4553/06/010001-18. doi:10.1007/s00024-0050005-y

Nocquet JM, Calais E (2004) Geodetic measurements of crustal deformation in the western Mediterranean and Europe, geodynamics of Azores-Tunisia. Pure \& Appl Geophys 161:661-681, 0033-4553/04/030661-21. doi:10.1007/s00024-003-2468-Z

Okada Y (1985) Surface deformation due to shear and tensile faults in a half-space. Bull Seismol Soc Am 75:1135-1154

Parsons B, Wright T, Rowe P, Andrews J, Jackson J, Walker R et al (2006) The 1994 Sefidabeh (eastern Iran) earthquakes revisited; new evidence from satellite radar interferometry and carbonate dating about the growth of an active fold above a blind thrust fault. Geophys J Int 164:202-217. doi:10.1111/j.1365-246X. 2005.02655.x

Philip H, Meghraoui M (1983) Structural analysis and interpretation of the surface deformations of the El Asnam earthquake of October 10, 1980. Tectonics 2: 17-49. doi:10.1029/TC002i001p00017

Rothé JP (1950) Les Séismes de Kherrata et la simicité de l'Algérie. Publ Serv Carte Geol Algérie 24:40

Salvi S et al (2000) Modeling coseismic displacements resulting from SAR interferometry and GPS mea- 
surements during the 1997 Umbria-Marche seismic sequence. J Seismol 4:479-499. doi:10.1023/A: 1026502803579

Scharoo R, Visser P (1998) Precise orbit determination and gravity field improvement for the ERS satellites. J Geophys Res 103:8113-8127. doi:10.1029/97JC03179

Serpelloni E, Vannucci G, Pondrelli S, Argnani A, Casula G, Anzidei M, Baldi P, Gasperini P (2007) Kinematics of the western Africa-Eurasia plate boundary from focal mechanism and GPS data. Geophys J Int 169:1180-1200. doi:10.1111/j.1365246X.2007.03367.x

Stein RS, Yeats RS (1989) Hidden earthquakes. Sci Am 260:30-39

Stich D, Ammon CJ, Morales J (2003) Moment tensor solutions for small and moderate earthquakes in the Ibero-Maghreb region. J Geophys Res 108, B3, 2148. doi:10.1029/2002JB002057
Wells DL, Coppersmith KJ (1994) New empirical relationships among magnitude, rupture length, rupture width, rupture area, and surface displacement. Bull Seismol Soc Am 84:974-1002

Wessel P, Smith HF (1998) New, improved version of the generic mapping tools released. Eos Trans AGU 79:579. doi:10.1029/98EO00426

Wright TJ, Lu Z, Wicks C (2004) Constraining the slip distribution and fault geometry of the Mw 7.9, 3 November 2002, Denali fault earthquake with interferometric synthetic aperture radar and global positioning system data. Bull Seismol Soc Am 94: S175-S189. doi:10.1785/0120040623

Yelles CAK, Djellit H, Beldjoudi H, Bezzeghoud M, Buforn E (2004) The Ain Temouchent (Algeria) earthquake of December 22nd, 1999, geodynamics of Azores-Tunisia. Pure Appl Geophys 161:607-621. doi:10.1007/s00024-003-2465-2 